\title{
Article/Artigo
}

\section{Prevalence of Mansonella ozzardi among riverine communities in the municipality of Lábrea, State of Amazonas, Brazil}

\author{
Prevalência de Mansonella ozzardi entre comunidades ribeirinhas do município de Lábrea, \\ Estado do Amazonas
}

\author{
Jansen Fernandes Medeiros ${ }^{1}$, Victor Py-Daniel ${ }^{2}$ and Ulysses Carvalho Barbosa ${ }^{2}$
}

\begin{abstract}
Introduction: Estimate the prevalence of Mansonella ozzardi infection and calculate the parasitic infection rate (PIR) in simuliid black flies in the municipality of Lábrea, State of Amazonas, Brazil. Methods: Prevalence was measured using the thick blood smear method collected from the fingers and was related to age, sex and occupation. Simuliidae were collected with a suction apparatus, then stained with hematoxylin and dissected to verify the PIR. Results: The average prevalence rate of $M$. ozzardi among the 694 individuals examined was $20.7 \%$. Infection was higher in men $(27.6 \%)$ than in women $(14.3 \%)(\mathrm{p}<0.001)$ and occurred in most age groups, with the highest prevalence in the following age groups: $38-47$ (40\%), 48-57 (53.1\%) and $>58(60.5 \%)$. The highest prevalence rates were observed in the retired (64\%), followed by farm workers (47.1\%). Infection by $M$. ozzardi was only identified in Cerqueirellum amazonicum (Simuliidae) with a PIR of $0.6 \%$. Conclusions: This study showed a high prevalence of $M$. ozzardi in the riverine communities of Lábrea due to the lack of policies regarding the treatment of microfilaremic individuals in the region and an abundance of competent vectors for M. ozzardi.
\end{abstract}

Keywords: Mansonelliasis. Mansonella ozzardi. Simuliidae. Municipality of Lábrea. Amazonas.

\section{RESUMO}

Introdução: Estimar as prevalências de Mansonella ozzardi, e calcular a taxa de infecção parasitária nos simulídeos no município de Lábrea, Estado do Amazonas. Métodos: As prevalências foram obtidas através do método de gota espessa a partir do sangue coletado da polpa digital e foram relacionadas com a idade, sexo e ocupação. Os simulídeos foram coletados com capturador de sucção, posteriormente foram corados com hematoxilina e dissecados para se obter a taxa de infecção parasitária. Resultados: A prevalência de $M$. ozzardi entre as 694 pessoas examinadas foi de $20,7 \%$. A infecção foi maior nos homens $(27,6 \%)$ do que nas mulheres $(14,3 \%)(\mathrm{p}<0,001)$ e ocorreu na maioria das faixas etárias com maiores prevalências nos indivíduos entre 38-47 (40\%), 48-57 (53,1\%) e >58 (60,5\%) anos. As maiores prevalências foram observadas nos aposentados (64\%) e agricultores (47,1\%). Somente Cerqueirellum amazonicum (Simuliidae) foi encontrado infectado com M. ozzardi com uma taxa de infecção parasitária de 0,6\%. Conclusões: Este trabalho mostra elevadas prevalências de $M$. ozzardi nas comunidades ribeirinhas de Lábrea devido à ausência de políticas de tratamento dos microfilarêmicos na região e a abundância de vetores competentes.

Palavras-chaves: Mansonelose. Mansonella ozzardi. Simuliidae. Município de Lábrea. Amazonas.

1. Coordenação de Pesquisas em Ciências da Saúde, Instituto Nacional de Pesquisas da Amazônia, Universidade do Estado do Amazonas, Manaus, AM. 2. Laboratório de EtnoEpidemiologia, Núcleo de Pesquisas em Ciências Humanas e Sociais, Instituto Nacional de Pesquisas da Amazônia, Manaus, AM.

Address to: Dr. Jansen Fernandes Medeiros. CPCS/INPA. Caixa Postal 478. Av. André Araújo 2936, Aleixo, 69060-001 Manaus, AM, Brasil.

Phone: 5592 3643-3288

e-mail: jmedeiro@gmail.com

Received in 03/03/2010

Accepted in 03/11/2010

\section{INTRODUCTION}

Mansonella ozzardi is a human filarial parasite that is distributed in parts of Central and South America and some Caribbean islands. Adult worms have rarely been captured, but appear to live in the mesentery and peritoneal cavity, while the microfilariae circulate mainly in the blood. They are transmitted by Diptera insects of the families Ceratopogonidae and Simuliidae ${ }^{1,2}$.

The pathogenicity of $M$. ozzardi remains unclear. Some reports have associated the presence of filarial worm with clinical manifestation, such as fever, coldness in the legs, joint pain and headaches ${ }^{3}$, but the frequency of these manifestations in endemic areas has not been studied. In some situations the presence of fever and chills appears similar to malaria, but unlike malaria, the symptoms of $M$. ozzardi do not have specific schedules, can occur during the day and cause damage to individuals in their daily functions ${ }^{4}$.

The microfilariae of $M$. ozzardi were detected in Brazil in the 1940s and 1950s s,6. Even though endemic areas had already been identified during this period in the State of Amazonas, along the Solimões, Purus and Negro Rivers and their tributaries ${ }^{7}$, at least one study predicted the neglect of this filarial disease $^{8}$. In the municipality of Lábrea, State of Amazonas, Brazil, studies between 1940s and 1980s reported prevalence rates varying from $0.4 \%$ to $4.4 \%^{7,9}$, while more recent studies have shown that prevalence continues increasing, reaching $30.2 \%$ among people living along the Ituxi river ${ }^{4}$.

As a part of our group's long-term study on the prevalence and distribution of filarial infection of humans in Brazil, a survey was conducted to determine the current status of M. ozzardi on the Purus river, in Lábrea. Thus, the study aimed to obtain data on human infection by $M$. ozzardi through comparison of prevalence rates between sexes and examine the relations between filarial infection and age and professional occupation. Identification of the simuliid species involved in the transmission of M. ozzardi and estimation of the parasitic infection rate (PIR) of these vectors was also performed. 


\section{METHODS}

This work was conducted in riverine communities on the Purus river in the municipality of Lábrea $\left(07^{\circ} 15 \mathrm{~S} / 64^{\circ} 51^{\prime} \mathrm{W}\right)$, State of Amazonas, Brazil (Figure 1). This municipality, with a population of 38,451 inhabitants, $80 \%$ of whom reside in urban areas ${ }^{10}$, is located in the southwest of the State of Amazonas.

The study was conducted in 23 communities selected at random along the Purus River: 1: Vila Dedé, 2: Santa Fé, 3: Ermídia, 4: Tamacuru, 5: Escritório, 6: Bela Rosa, 7: Realeza, 8: Praia da Gaivota, 9: Várzea Grande, 10: Luzitânea, 11: Santa Cruz, 12: Cachoeira do Hilário, 13: Santa Vitória, 14: Asimã, 15: Remanso do Itanaãa, 16: Cacau, 17: Porongaba, 18: Nova Morada, 19: Santa Eugênia, 20: São Gerônimo, 21: Nazaré, 22: Mucuripe, and 23: Passeá), as presented in Figure 1. The populations mainly practice subsistence farming (fishing and some vegetable and fruit farming, including cassava and bananas) and raising animals (cows, pigs and chickens) on a small scale. The average yearly rainfall in Lábrea fluctuates between 2,400 and $2,600 \mathrm{~mm}$. The temperature usually ranges between 24 and $26^{\circ} \mathrm{C}$ and relative humidity between 85 and $95 \%$.

The population in the rural areas in Lábrea is approximately 7,690 ( $20 \%$ of the total population $)^{10}$. The sample size was determined by assuming an expected prevalence of $M$. ozzardi of $30.2 \%{ }^{4}$ with an error of $12 \%$ and confidence interval of $95 \%$. The population density is low, such that at least $20 \%$ in the communities was examined. The study was conducted in communities through convenience samples. Individuals that were present at the moment of study and informed of the purpose and scope of the study were invited to participate. A total of 694 individuals between 2 and 88 years-old $($ mean $=22.9 \pm 17.6)$ were examined by Rapid Epidemiological Mapping for microfilariae (mf) of M. ozzardi in April 2006 and August 2007.

Estimation of M. ozzardi prevalence was performed using thick blood smears obtained by digital punctures. Two drops of blood

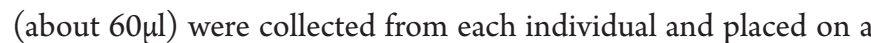
slide. After air-drying, the blood was dehemoglobinized, stained with Giemsa, placed under a microscope for identification of the species of microfilariae present ${ }^{11}$.

The evaluation of prevalence took into account the following data: sex; age group, 2-9, 10-18, 19-27, 28-37, 38-47, 48-57, 58-67 and $\geq 68$ years-old; occupation, farm worker, housewife, student, teacher, retiree ( $\operatorname{man} \geq 65$ and women $\geq 60$ years-old) and those with not occupation $(<5 \text { years-old })^{12}$. Prevalences between the sexes were compared by the $\mathrm{x}^{2}$ test and the differences between age groups were compared using the maximum likelihood Chi square G-test. Differences in microfilaremia between the sexes were assessed by the Mann Whitney U test and microfilaremiae counts and age were analyzed using Spearman's correlation.

Simuliidae were caught in the communities by a rapid entomological assessment technique using manual suction collectors. The flies were identified in the laboratory, stained with acid hematoxylin and dissected. The simuliidae collected were dissected into three parts (head, thorax, and abdomen) using a stylet, under a stereoscopic microscope $\mathrm{e}^{13}$. When filarial worms were detected, they were identified and quantified regarding developmental stage $\left(\mathrm{L}_{1}, \mathrm{~L}_{2} \text {, or } \mathrm{L}_{3}\right)^{14}$. The parasitic infection rate (PIR) was calculated by the number of females infected with stage $\mathrm{L}_{1}, \mathrm{~L}_{2}$ and/or $\mathrm{L}_{3} M$. ozzardi divided by the number of females dissected, multiplied by 100 .

\section{Ethical considerations}

This study was approved by the Research Ethics Committee of the National Institute of Amazonian Research (Instituto Nacional de Pesquisas da Amazônia, INPA), Manaus, Amazonas, Brazil, under process no. 043/2005. Free, informed consent was obtained from all adult participants during meetings with the community and from parents in the case of minors.

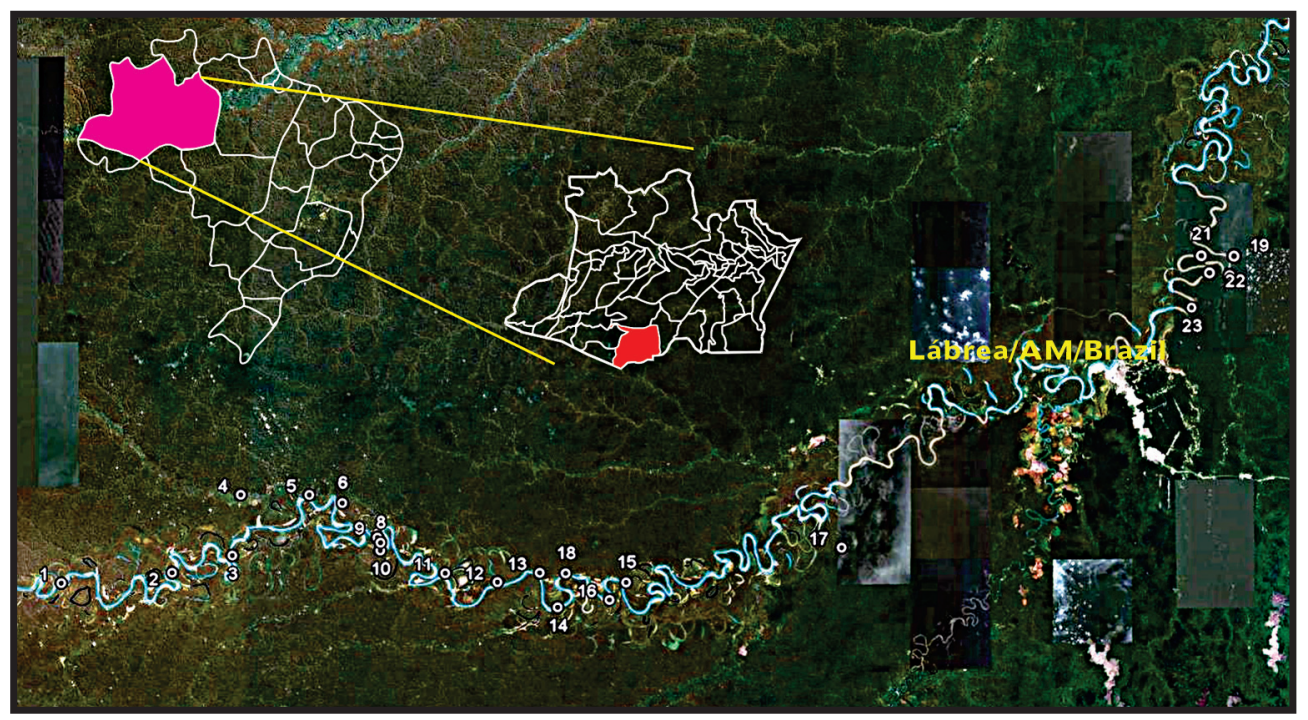

FIGURE 1 - Location of the 23 riverine study communities along the Purus river, municipality of Lábrea, State of Amazonas, Brazil.

1: Vila Dedé, 2: Santa Fé, 3: Ermídia, 4: Tamacuru, 5: Escritório, 6: Bela Rosa, 7: Realeza, 8: Praia da Gaivota, 9: Várzea Grande, 10: Luzitânea, 11: Santa Cruz, 12: Cachoeira do Hilário, 13: Santa Vitória, 14: Asimã, 15: Remanso do Itanaã, 16: Cacau, 17: Porongaba, 18: Nova Morada, 19: Santa Eugênia, 20: São Gerônimo, 21: Nazaré, 22: Mucuripe, 23: Passeá. 


\section{RESULTS}

Of the 694 individuals examined, 144 (20.7\%) were M. ozzardi positive, with prevalence that varied from $8.4 \%$ to $62.5 \%$ in different communities (Table 1).

The distribution of individuals with $M$. ozzardi according to sex and age is presented in Table 2. Men exhibited significantly higher prevalence than women $(27.6 \%$ vs $14.3 \%$; Chi square $\mathrm{p}<0.001)$. The lowest prevalence was observed in the group of individuals between 2 and 9 years-old (4.9\%). The percentage of microfilaremic individuals increased linearly with age $(r=0.96$, $\mathrm{p}<0.001$; Spearman's correlation), with the highest indices of infection in individuals over 58 years of age $(\mathrm{men}=66.7 \%$ and women $=55 \%)$. With the exception of individuals between 2 and 9 years of age, in all the other age groups, men presented higher prevalence than women, with significant differences verified for the age groups 19-27, 28-37 and 38-47 ( $<$ 0.001) (Table 2).

Regarding occupation, retirees showed the highest prevalence (64\%) followed by farm workers (47.4\%). Infection was least prevalent in children under 5 (no occupation - 3.8\%) and students (8.9\%) (Table 3).

Microfilaremia was higher in men than in women, but this difference was not significant (32.01 vs $19.36 \mathrm{mf} / 40 \mu \mathrm{l} \mathrm{blood;} \mathrm{Mann}$ Whitney $\mathrm{p}=0.27$ ); while the highest concentrations were verified in retirees and farm workers (Table 3). Overall microfilaremia was

TABLE 1 - Mansonella ozzardi infections in communities along the Purus River, municipality of Lábrea, State of Amazonas, Brazil.

\begin{tabular}{|c|c|c|c|c|c|c|c|c|c|c|}
\hline \multirow[b]{2}{*}{ Communities } & \multirow{2}{*}{$\begin{array}{c}\text { Total } \\
\text { population* }\end{array}$} & \multicolumn{3}{|c|}{ Males } & \multicolumn{3}{|c|}{ Females } & \multicolumn{3}{|c|}{ Total } \\
\hline & & ex & pos & $\overline{\operatorname{prev}(\%)}$ & ex & pos & $\overline{\operatorname{prev}(\%)}$ & ex & pos & prev (\%) \\
\hline Vila Dedé & 96 & 21 & 2 & 9.5 & 22 & 2 & 9.1 & 43 & 4 & 9.3 \\
\hline Santa Fé & 280 & 41 & 11 & 26.8 & 38 & 9 & 23.7 & 79 & 20 & 25.3 \\
\hline Ermídia & 125 & 21 & 9 & 42.7 & 19 & 3 & 15.8 & 40 & 12 & 30.0 \\
\hline Tamacuru & 63 & 11 & 4 & 36.4 & 16 & 2 & 12.5 & 27 & 6 & 22.2 \\
\hline Escritório & 79 & 19 & 4 & 21.0 & 13 & 0 & 0.0 & 32 & 4 & 12.5 \\
\hline Bela Rosa & 93 & 23 & 6 & 26.1 & 20 & 8 & 40.0 & 43 & 14 & 32.5 \\
\hline Realeza & 48 & 9 & 1 & 11.1 & 9 & 1 & 11.1 & 18 & 2 & 11.1 \\
\hline Praia da Gaivota & 30 & 5 & 1 & 20.0 & 7 & 1 & 14.3 & 12 & 2 & 16.6 \\
\hline Várzea Grande & 85 & 21 & 7 & 33.3 & 35 & 3 & 8.6 & 56 & 10 & 17.8 \\
\hline Luzitânea & 34 & 2 & 0 & 0.0 & 2 & 1 & 50.0 & 4 & 1 & 25.0 \\
\hline Santa Cruz & 42 & 12 & 6 & 50.0 & 17 & 3 & 17.5 & 29 & 9 & 31.0 \\
\hline Cachoeira do Hilário & 193 & 31 & 3 & 9.7 & 28 & 2 & 7.1 & 59 & 5 & 8.5 \\
\hline Santa Vitória & 65 & 10 & 2 & 20.0 & 10 & 3 & 30.0 & 20 & 5 & 25.0 \\
\hline Asimã & 166 & 37 & 9 & 24.3 & 46 & 6 & 13.0 & 83 & 15 & 18.1 \\
\hline Remanso do Itanaã & 41 & 12 & 6 & 50.0 & 15 & 1 & 6.6 & 27 & 7 & 25.9 \\
\hline Cacau & 90 & 17 & 4 & 23.5 & 15 & 4 & 26.7 & 32 & 8 & 25.0 \\
\hline Porongaba & 80 & 8 & 2 & 25.0 & 13 & 2 & 15.4 & 21 & 4 & 19.1 \\
\hline Nova Morada & 43 & 12 & 2 & 16.0 & 12 & 0 & 0.0 & 24 & 2 & 8.3 \\
\hline Santa Eugênia & 15 & 5 & 2 & 40.0 & 3 & 1 & 33.3 & 8 & 3 & 37.5 \\
\hline São Gerônimo & 22 & 5 & 3 & 60.0 & 3 & 0 & 0.0 & 8 & 3 & 37.5 \\
\hline Nazaré & 25 & 6 & 4 & 66.7 & 2 & 1 & 50.0 & 8 & 5 & 62.5 \\
\hline Mucuripe & 33 & 2 & 1 & 50.0 & 5 & 0 & 0.0 & 7 & 1 & 14.3 \\
\hline Passeá & 52 & 7 & 6 & 85.7 & 7 & 1 & 14.3 & 14 & 7 & 50.0 \\
\hline
\end{tabular}

TABLE 2 - Prevalence of infection by Mansonella ozzardi microfilariae according to age and sex in communities along the Purus River, municipality of Labrea, State of Amazonas, Brazil.

\begin{tabular}{|c|c|c|c|c|c|c|c|c|c|}
\hline \multirow[b]{2}{*}{ Age group } & \multicolumn{3}{|c|}{ Males } & \multicolumn{3}{|c|}{ Females } & \multicolumn{3}{|c|}{ Total } \\
\hline & ex & pos & $\overline{\operatorname{prev}(\%)}$ & ex & pos & prev (\%) & ex & pos & prev (\%) \\
\hline $2-9$ & 90 & 4 & 4.4 & 93 & 5 & 5.4 & 183 & 9 & 4.9 \\
\hline $10-18$ & 84 & 11 & 13.1 & 93 & 7 & 7.5 & 177 & 18 & 10.2 \\
\hline $19-27$ & 54 & 19 & $35.2^{*}$ & 50 & 5 & $10.0^{*}$ & 104 & 24 & 23.1 \\
\hline $28-37$ & 41 & 17 & $41.4^{*}$ & 49 & 8 & $16.3^{*}$ & 90 & 25 & 27.8 \\
\hline $38-47$ & 33 & 20 & $60.6^{*}$ & 37 & 8 & $21.6^{*}$ & 70 & 28 & 40.0 \\
\hline $48-57$ & 17 & 10 & 58.8 & 15 & 7 & 46.6 & 32 & 17 & 53.1 \\
\hline$>58$ & 18 & 12 & 66.6 & 20 & 11 & 55.0 & 38 & 23 & 60.5 \\
\hline Total & 337 & 93 & 27.6 & 357 & 51 & 14.3 & 694 & 144 & 20.7 \\
\hline
\end{tabular}

ex: examined, pos: positive, prev (\%): prevalence (\%), ${ }^{*}$ correspond to statistical significant difference $(\mathrm{p}<0.001)$ between males and females in different age groups, using G-test. 
TABLE 3 - Prevalence of infection by Mansonella ozzardi according to the occupation of individuals in communities along the Purus River, municipality of Lábrea, State of Amazonas, Brazil.

\begin{tabular}{lcccc}
\hline Occupation & Examined & Positive & $\begin{array}{c}\text { Prevalence } \\
(\%)\end{array}$ & $\begin{array}{c}\text { Mean of microfilariae/ } \\
60 \mu \text { l of blood }\end{array}$ \\
\hline Farm worker & 153 & 72 & 47.1 & $44.8 \pm 50.5$ \\
\hline Retired & 25 & 16 & 64.0 & $67.7 \pm 84.4$ \\
\hline Housewife & 152 & 25 & 16.4 & $14.8 \pm 17.23$ \\
\hline Student & 304 & 27 & 8.9 & $5.7 \pm 7.7$ \\
\hline No occupation & 52 & 2 & 3.8 & $24.0 \pm 35.5$ \\
\hline Other $^{* *}$ & 8 & 2 & 25.0 & $2.50 \pm 0.70$ \\
\hline Total & $\mathbf{6 9 4}$ & $\mathbf{1 4 4}$ & $\mathbf{2 0 . 7}$ & $\mathbf{3 2 . 1} \pm \mathbf{4 8 . 8}$
\end{tabular}

*children (2-5 years old), ${ }^{* *}$ three healthcare professionals, one blind person, two fisherman and two teachers. low, with most individuals ( 86 - 59.7\%) presenting between 1 and $9 \mathrm{mf} / 40 \mu \mathrm{l}$ and was higher in individuals over 38 years of age $(\mathrm{r}=0.44$, $\mathrm{p}<0.001)$ (Table 4).

All of the simuliidae collected were identified as Cerqueirellum amazonicum. A total of 1,832 simuliidae were collected, but only 11 were infected; the PIR was $0.6 \%$. Four $(0.2 \%)$ simuliids with $\mathrm{L}_{1}$, four (0.2\%) with $\mathrm{L}_{2}$ and three $(0.16 \%)$ com $\mathrm{L}_{3}$. Of the 13 communities where simuliidae were collected, infected flies were identified in 8: Tamacuru, 82 simuliidae collected, 2 infected, PIR of $2.4 \%$; Escritório, 141 simuliidae collected, 1 infected, PIR of 0.7\%; Bela Rosa, 169 simuliidae collected, 1 infected, of $0.6 \%$; Várzea Grande, 164 simuliidae collected, 1 infected, PIR of 0.6\%; Luzitânea, 177 simuliidae collected, 3 infected, PIR of 1.7\%; Porongaba, 196 simuliidae collected, 2 infected, PIR of 1\%; Nova Morada, 231 simuliidae collected, 1 infected, PIR of $0.4 \%$. The majority of M. ozzardi larvae were stage $L_{2}(12)$ followed by stages $L_{1}(8)$ and $L_{3}(5)$.

\begin{tabular}{|c|c|c|c|c|c|c|c|}
\hline \multirow[b]{2}{*}{ Age group } & \multicolumn{5}{|c|}{ Number of microfilariae $/ 60 \mu \mathrm{l}$ of blood } & \multirow{2}{*}{$\begin{array}{l}\text { Positive } \\
\text { infected }\end{array}$} & \multirow{2}{*}{$\begin{array}{c}\text { Mean of microfilariae/ } \\
60 \mu \mathrm{l} \text { of blood }\end{array}$} \\
\hline & $1-9$ & $10-19$ & $20-49$ & $50-99$ & $>100$ & & \\
\hline $2-9$ & 7 & 1 & 1 & 0 & 0 & 9 & $9.7 \pm 15.9$ \\
\hline $10-18$ & 15 & 1 & 2 & 0 & 0 & 18 & $5.9 \pm 8.5$ \\
\hline $19-27$ & 15 & 4 & 3 & 2 & 0 & 24 & $12.9 \pm 18.8$ \\
\hline $28-37$ & 13 & 3 & 3 & 4 & 2 & 25 & $26.5 \pm 36.1$ \\
\hline $38-47$ & 16 & 3 & 3 & 4 & 2 & 28 & $40.6 \pm 55.6$ \\
\hline $48-57$ & 7 & 3 & 2 & 2 & 3 & 17 & $38.1 \pm 46.7$ \\
\hline$>58$ & 13 & 2 & 2 & 1 & 5 & 23 & $44.7 \pm 70.6$ \\
\hline Total & 86 & 17 & 16 & 13 & 12 & 144 & $32.1 \pm 48.8$ \\
\hline
\end{tabular}

\section{DISCUSSION}

This work confirms that $M$. ozzardi prevalence has increased in Lábrea: currently registering $20.7 \%$, which represents a 41.5 -fold increase in relation to that reported by Lacerda \& Rachou $(0.4 \%)^{7}$ in 1956 and 4.7 -fold in relation to that reported by Shelley $(4.4 \%)^{9}$ in 1975. This increase also was observed on the Ituxi River ${ }^{4}$, where a 5.1-fold increase was verified in relation to that reported by Tavares $(5.9 \%)^{15}$ in 1981.

The present results show that prevalence increases linearly with age, a result that is in agreement with other studies ${ }^{12,15-18}$. Older individuals with greater exposure to open air contract the infection with greater regularity, whereas younger individuals whose daily agenda includes closer proximity to home and school are apparently less exposed. The greater exposure to the vectors explains the higher infection rates in men than in women, also confirmed in other studies $^{12,17,19}$. In certain age groups $(19-27,28-37,38-47)$, men showed much higher prevalence than women, possibly explained as a by-product of different occupations. Whereas men have greater exposure to vectors due to their daily activities, women are less exposed as they typically maintain day-to-day activities close to home.

Observation verified that among men and women over the age of 48 , the rates of prevalence of infection were very similar. Some evidence exists that during the in individuals 50 years-old or over, prevalence for M. ozzardi in both sexes becomes virtually the same ${ }^{18}$. The similarity in prevalence rates between older men and women could be an artifact of the changing daily habits of men with age, as they tend to live a more sedentary lives, similar to the daily routine of women, thus farther removed from direct exposure to vectors.

The microfilariae load was highest among those aged over 38 years-old. These observations indicate that the high microfilaremia level determined in those over 40 is probably due to a continuum of overlapping infections. These findings are in agreement with observations reported in Bolivia, where the microfilaria loads using the finger prick method were lowest in children and increased with age $(>100 \mathrm{mf} / 20 \mu \mathrm{l} \text { blood observed in people }>44 \text { years-old })^{18}$. Monkeys were used as experimental hosts to monitor the microfilaremia of M. ozzardi. After a mean prepatent period of 163 days, microfilaremia increased, peaking at around 20 weeks, and then decreased, stabilizing at low levels for up to 48 weeks ${ }^{20}$. Microfilariae density was significantly higher in males. These results are similar to those verified among inhabitants of Colombia, based on a Knott's sample $(\mathrm{mf} / \mathrm{ml})^{21}$ and also in studies with Wuchereria bancrofti using polycarbonate membrane filtration in Brazil ${ }^{22}$. It should be noted, however, that mf-counts are highly variable between smears from an individual due to variations in blood sampling time ${ }^{23}$ and short-term variation in mf density ${ }^{23-25}$.

The highest prevalence was determined in retirees, suggesting that these individuals could have suffered a continuous succession of overlapping infections that remained untreated during their lifetime. Farm workers represent the second most microfilaremic group, again confirming that individuals working in agricultural fields, in contact with the forest environment, or along river margins, are more exposed to simuliidae and therefore present greater prevalence of infection than other occupations. Most epidemiological studies of $M$. ozzardi report that individuals who work in the open air show higher prevalence rates ${ }^{9,12,26}$. 
This study verified that C. amazonicum is the vector of M. ozzardi in communities of Lábrea situated along the Purus River, confirming the reports of other researchers ${ }^{27}$. The PIR $(0.6 \%)$ and number of $\mathrm{L}_{1}, \mathrm{~L}_{2}$ and $\mathrm{L}_{3}$ larvae were low. A low PIR (0.9\%) was previously determined in simuliidae captured along the Purus river, in the municipality of Lábrea ${ }^{27}$. It is possible that PIR vary during the year in relation to numerous factors, including microfilarial density and the degree of exposure of inhabitants to vectors. However, to understand the dynamics in the transmission of M. ozzardi along the Purus river, studies should be conducted over extended time intervals and include both the dry and rainy seasons.

This study reports a strong temporal increase in prevalence rates over time in the region of Lábrea. However, a long-term policy of treatment for microfilaremic individuals in the region remains inaccessible, while the policies that do exist are short lived and local, a strategy which fails to attend the majority affected by M. ozzardi. This is most likely the principal reason why the prevalence of Mansonella ozzardi has continued to grow for several decades.

\section{ACKNOWLEDGMENTS}

The authors would like to thank the Fundação Nacional de Saúde in the municipality of Pauini for the logistical support.

\section{CONFLICT OF INTEREST}

The authors declare that there is no conflict of interest.

\section{FINANCIAL SUPPORT}

Fundação de Amparo à Pesquisa do Estado do Amazonas (FAPEAM; Proc. 2205/05).

\section{REFERENCES}

1. Cerqueira NL. Sobre a transmissão da Mansonella ozzardi. J Bras Med 1959; 1:885-914.

2. Shelley AJ, Shelley A. Further evidence for the transmission of Mansonella ozzardi by Simulium amazonicum in Brazil. Ann Trop Med Parasitol 1976; 70:213-217.

3. Batista D, Oliveira WR, Rabello VD. Estudo da patogenicidade da Mansonella ozzardi e da sintomatologia da mansonelose. Rev Inst Med Trop São Paulo 1960; 2:281-289.

4. Medeiros JF, Py-Daniel V, Barbosa UC, Ogawa GM. Current profile of Mansonella ozzardi (Nematoda: Onchocercidae) in communities along the Ituxi river, Lábrea municipality, Amazonas, Brazil. Mem Inst Oswaldo Cruz 2008; 103:409-411.

5. Deane MP. Sobre a incidência de filárias humanas em Manaus, Estado do Amazonas. Rev Serv Esp Saude Publica 1949; 2:849-858.

6. Deane L, Rachou RG, Lacerda NB, Martins JB. Alguns dados relativos à prevalência de Mansonella ozzardi no Brasil. Rev Bras Malariol Doenças Trop 1954; 6:219-224.

7. Lacerda NB, Rachou RG. Filarioses humanas nas sedes municipais do estado do Amazonas e territórios do Acre, Guaporé e Rio Branco. Rev Bras Malariol Doenças Trop 1956; 8:437-442.

8. Moraes MAP. Contribuição ao estudo da mansonelose do Amazonas. O Hosp 1958; 54:887-892.

9. Shelley AJ.A preliminary survey of the prevalence of Mansonella ozzardi in some rural communities on the river Purus, state of Amazonas, Brazil. Ann Trop Med Parasitol 1975; 69:407-412.

10. Instituto Brasileiro de Geografia e Estatística [Internet]. Rio de Janeiro: Censo 2008 População e Domicílios 2008 - [2010 march 3]. Available from: www.ibge.gov.br/.
11. Post RJ, Adams ZA, Shelley AJ, Maia-Herzog M, Luna-Dias APA, Coscarón S. The morphological discrimination of microfilariae of Onchocerca volvulus from Mansonella ozzardi. Parasitology 2003; 127:21-27.

12. Medeiros JF, Py-Daniel V, Barbosa UC, Izzo TJ. Mansonella ozzardi in Brazil: prevalence of infection in riverine communities in the Purus region, in the state of Amazonas. Mem Inst Oswaldo Cruz 2009; 104:74-80.

13. Medeiros JF, Py-Daniel V, Barbosa UC, Farias ES. Epidemiological studies of Mansonella ozzardi (Nematoda, Onchocercidae) in indigenous communities of Pauini municipality, Amazonas, Brazil. Acta Amaz 2007; 37:241-246.

14. Yazarbal L, Basáñez MG, Ramírez-Pérez J, Ramírez A, Botto C, Yazarbal A. Experimental and natural infection of Simulium sanchezi by Mansonella ozzardi in the middle Orinoco region of Venezuela. Trans R Soc Trop Med Hyg 1985; 79:29-33.

15. Tavares AM.Estudo da infecção por Mansonella ozzardi. [Dissertação]. [Brasília]: Universidade de Brasília; 1981.122p.

16. Lawrence ND, Erdtmann B, Peet JW, Nunes de Mello JA, Hearl GR, James V, et al. Estudos epidemiológicos entre populações indígenas da Amazônia. II. Prevalência da microfilaremia de M. ozzardi: Comparação de dois métodos de diagnóstico. Acta Amaz 1980; 10:763-769.

17. Kozek WJ, D’Alessandro A, Suva J, Navarrete S. Filariasis in Colombia: Prevalence of mansonellosis in the teenage and adult population of the Colombian bank of the Amazon River, Comisaria del Amazonas. Am J Trop Med Hyg 1982; 31:1131-1136.

18. Bartoloni A, Cancrini G, Bartelesi F, Marcolin D, Roselli M, Arce CC, et al. Mansonella ozzardi infection in Bolivia: prevalence and clinical association in the Chacon region. Am J Trop Med Hyg 1999; 61:830-833.

19. Medeiros JF, Py-Daniel V, Barbosa UC, Ogawa GM. Ocorrência da Mansonella ozzardi (Nematoda, Onchocercidae) em comunidades ribeirinhas do rio Purus, Município de Boca do Acre, Amazonas, Brasil. Cad Saude Publica $2009 ; 25: 1421-1426$.

20. Orihel TC, Eberhard ML, Lowrie Jr RC. Mansonella ozzardi: the course of the patency in experimentally infected patas monkeys. Trop Med Parasitol 1993; 44:49-54.

21. Kozek WJ, Palma G, Henao A, Garcia H, Hoyos M. Filariasis in Colombia Prevalence and distribution of Mansonella ozzardi and Mansonella (=Dipetalonema) perstans infections in the Comisaría del Guainía. Am J Trop Med Hyg 1983; 32:379-384.

22. Rocha EMM, Fontes G, Brito AC, Silva TRC, Medeiros Z, Antunes CMF Filariose bancroftiana em áreas urbanas do Estado de Alagoas, nordeste do Brasil: estudo em população geral. Rev Soc Bras Med Trop 2000; 33:545-551.

23. Simonsen PE, Niemann L, Meyrowitsch DW. Wuchereria bancrofti in Tanzania: microfilarial periodicity and effect of blood sampling time on microfilarial intensities. Trop Med Int Health 1997; 2:153-158.

24. Dreyer G, Pimentael A, Medeiros Z, Beliz F, Moura I, Coutinho A, et al. Studies on the periodicity and intravascular distribution of Wuchereria bancrofti microfilariae in paired samples of capillary and venous blood from Recife, Brazil. Trop Med Int Health 1996; 1:264-272.

25. Pichon G, Riviere F, Thirel R, Chebret M, Tetuanui A, Toudic A. Fluctuations affecting the measurement of microfilaremia. Bull Soc Pathol Exot Filiales $1981 ; 74: 525-532$.

26. Batista D, Cerqueira NL, Moraes MAP. Epidemiologia da mansonelose em localidade do interior do Amazonas. Rev Assoc Med Bras 1960; 6:176-184.

27. Shelley AJ, Coscarón S. Simuliid blackflies (Diptera: Simuliidae) and Ceratopogonid midges (Diptera: Ceratopogonidae) as vectors of Mansonella ozzardi (Nematoda: Onchocercidae) in Northern Argentina. Mem Inst Oswaldo Cruz 2001; 96:451-458. 